Hj.Eveline Fifiana, Eksistensi Kekuasaan Kehakiman (Judicative Power) Dalam Mewujudkan Indepedensi Peradilan Dan Peradilan Yang Bersih

Halaman 266-273

\title{
EKSISTENSI KEKUASAAN KEHAKIMAN ( JUDICATIVE POWER) DALAM MEWUJUDKAN INDEPEDENSI PERADILAN DAN PERADILAN YANG BERSIH
}

\author{
Hj. Eveline Fifiana \\ Sekolah Tinggi Ilmu Hukum Sumpah Pemuda Palembang \\ fifianaeveline@gmail.com
}

\begin{abstract}
Every Indonesian citizen has the obligation to uphold the applicable law. Every implemented law has a demand for justice. Judicial power must exist in every democratic State of Law, tasked with upholding and overseeing the enactment of the applicable law and regulations (ius constitutum) in order to realize justice. Law without justice will be in vain, as a result, law will become invaluable before community. To answer the problems in this study, the researcher used a normative juridical approach, descriptive qualitative in nature. In this research, law enforcers, especially judges, must uphold the authority of the law and uphold the value of trust in society. The important prerequisites in upholding law and justice in the wolrd of justice is noble, clean, honest, professional, high integrity, high moral, and dignified judge. Supreme Court and Constitutional Court as judicial power holders, along with Judicial Commision in the scope of judiciary powers, not only have the authority to guide the judges but also have the authority to maintain the independency of judiciary powers from the influence of government and outside government parties by minimizing the subjectivity in recruitment process of prospective judges and supreme judges. The independency of judicial power is not enough, because law enforcers, especially "bad" judges can take refugee under the independency of judicial power. To build an "ideal" Judge or Supreme Judge who will fulfill the people needs of justice, the Judge or Supreme Judge recruitment process conducted by Judical Commission need to be strict while increasing the control over the implementation of power to minimize the arbitrary acts and abusive judge's power. High commitment, consistency, adhering to the principles and code of ethics in carrying out their duties will lead to a clean, authoritative judiciary in the eyes of the society so that the hope of upholding independent judicial power will be realized while at the same time bring improvements to the Indonesian justice situation.
\end{abstract}

Keywords : Independency; Judicial Power; Judiciary; Judge; Justice

\section{ABSTRAK}

Setiap warganegara Indonesia yang baik punya kewajiban menjunjung tinggi hukum yang.berlaku. Setiap hukum yang dilaksanakan ada tuntutan untuk memperoleh suatu keadilan. Kekuasaan Kehakiman harus ada pada setiap Negara hukum yang demokratis, bertugas menegakkan dan mengawasi berlakunya peraturan perundang- undangan yang berlaku ( ius constitutum ) agar terwujudnya suatu keadilan. Hukum tanpa keadilan akan siasia, akibatnya hukum akan menjadi tidak berharga dihadapan masyarakat. Untuk menjawab permasalahan dalam penelitian ini Peneliti menggunakan metode pendekatan yuridis normatif yang bersifat deskriptif kualitatif. Dalam penelitian ini para penegak hukum dalam hal ini khususnya Hakim, pada hakekatnya harus menegakkan wibawa hukum sekaligus akan ,menegakkan nilai kepercayaan di dalam masyarakat. Prasyarat penting dan utama dalam menegakkan hukum dan keadilan dalam dunia peradilan, seorang Hakim dituntut harus berbudi pekerti luhur, bersih, jujur, professional, berintegritas tinggi, bermoral dan bermartabat. Mahkamah Agung ( MA) dan Mahkamah Konstitusi ( MK) sebagai pemegang kekuasaan kehakiman sedangkan keberadan Komisi Yudisial (KY) dalam lingkup kekuasaan Kehakiman disamping punya kewenangan melakukan pembinaan hakim juga menjaga 
Hj.Eveline Fifiana, Eksistensi Kekuasaan Kehakiman (Judicative Power) Dalam Mewujudkan Indepedensi Peradilan Dan Peradilan Yang Bersih

Halaman 266-273

indepedensi kekuasaan kehakiman terhadap pengaruh pemerintah maupun pihak diluar pemerintah, mengurangi subyektifvitas dalam rekrutmen penerimaan calon hakim dan calon hakim agung. Indenpedensi kekuasaan kehakiman saja tidaklah cukup, karena penegak hukum khususnya Hakim dengan perilaku "tidak baik" dapat saja berlindung dibawah indepedensi kekuasaan kehakiman. Untuk memperoleh seorang Hakim , Hakim Agung yang "ideal" yang akan memenuhi keinginan masyarakat sebagai pencari keadilan, dimulai dari seleksi rekrutmen Hakim , Hakim Agung oleh Komisi Yudisial secara ketat, disamping itu perlu peningkatan kontrol terhadap pelaksanaan kekuasaan agar tidak menimbulkan tindakan kesewenang wenangan dan penyalahgunaan kekuasaan hakim. Komitmen tinggi, konsisten, berpegang teguh pada prinsip serta kode etik dalam menjalankan tugas nya akan menuju peradilan yang bersih, berwibawa dimata masyarakat sehingga harapan untuk menegakkan kekuasaan kehakiman yang independen akan terwujud sekaligus membawa perbaikan dunia peradilan Indonesia.

Kata Kunci : Indepedensi; Kekuasaan Kehakiman; Peradilan; Hakim; Keadilan.

\section{PENDAHULUAN}

Indonesia merupakan Negara yang berdasarkan atas hukum dengan menganut sistem konstitusionalisme, sebagaimana tertuang didalam amandemen keempat Undang Undang dasar tahun 1945 pasal 1 ayat 3 menyebutkan Negara Indonesia adalah Negara hukum. ${ }^{1}$ Setiap warganegara yang baik punya kewajiban untuk menjunjung tinggi hukum yang berlaku. Hukum merupakan perwujudan atau manifestasi dari nilai kepercayaan. Akan menjadi suatu hal yang wajar apabila para penegak hukum diharapkan sebagai orang yang sepatutnya dipercaya yang pada hakekatnya harus menegakkan wibawa hukum, yang berarti menegakkan nilai kepercayaan di dalam masyarakat. Nilai kepercayaan merupakan salah satu nilai atau kepentingan masyarakat yang perlu selalu dipelihara, ditegakkan dan dilindungi. Nilai kepercayaan akan menjalin hubungan harmonis dalam kehidupan bermasyarakat dan bernegara, tetapi akan menjadi sebaliknya justru akan timbul kekacauan , ketidaktentraman apabila nilai kepercayaan ini telah hilang atau mengalami erosi didalam kehidupan bermasyarakat. Hal ini dapat terlihat umpamanya pada perilak seseorang yang

${ }^{1}$ Sudiro Ahmad,Dr dan Deni Bram,Dr.

Hukum dan Keadilan( aspek nasional \& internasional), PTRaja Grafindo Persada, Jakarta, 2013, hlm.123. tugas yuridisnya sebagai aparat penegak hukum antara lain Hakim, Jaksa, Polisi, mengusahakan ketaatan atau kepatuhan hukum warga masyarakat, tetapi justru penegak hukum itu sendiri berperilaku sebaliknya, sehingga tidak dapat dijadikan suatu teladan oleh warga masyarakat.

Eksistensi hukum sangat diperlukan dalam mengatur kehidupan manusia, karena tanpa hukum kehidupan manusia akan liar. Tujuan hukum adalah untuk melindungi kepentingan manusia dalam mempertahankan hak dan kewajibannya. Hukum mempunyai tugas untuk menjamin adanya kepastian hukum dalam masyarakat. Penegakan hukum itu harus sudah mulai sejak pembuatan peraturan hukumnya ( law making) sampai kepada penjabarannya kasus perkasus ${ }^{2}$. Dalam hal ini berarti komponrn penegak hukum itu sudah mulai dari kegiatan legisllatif untuk menyusun dan menetapkan hukum yang dinilai ideal yang dalam arti hukum mampu memberikan keadilan, kepastian hukum dan kemanfaatan hukum bsgi pencari keadilan.Untuk menegakkan aturan aturan hukum tersebut tentunya diperlukan suatu institusi, salah satunya yaitu Kekuasaan Kehakiman.

\footnotetext{
${ }^{2}$ Solly Lubis,Prof.Dr.SH., Kebijakan

Publik, Mandar Maju, Bandung, 2007.
} 
Keberadaan lembaga Kekuasaan Kehakiman ( Pengadilan) merupakan ciri utama dan akarnya Negara hukum. Tidak ada Negara hukum tanpa ada kekuasaan kehakiman. Kekuasaan Peradilan yang bebas dan tidak memihak ( independent and impartial judiciary) mutlak harus ada dalam setiap Negara Hukum ${ }^{3}$. Kekuasaan Kehakiman bukan hanya semata mata sebagai lembaga penyelesaian sengketa yang bersifat netral tetapi sebagai pembentuk hukum dan politik hukum melalui putusan -putusannya. ${ }^{4}$. Fungsi utama Kekuasaan Kehakiman adalah memutus sengketa ( resolving disputes) antara individu dengan individu, individu dengan masyarakat bahkan individu atau masyarakat dengan Negara dan fungsi kedua adalah membentuk atau membuat policy atau kebijakan. ${ }^{5}$ Kebijakan hukum yang menyatakan perlunya kekuasaan kehakiman yangbersifat indepeden seperti yang tercantum dalam Pasal 24 ayat 1 Undang Undang Dasar 1945yang berbunyi "Kekuasaan kehakiman adalah kekuasaan yang merdeka untuk menyelenggarakan peradilan guna menegakkan Hukum dan Keadilan“ Hal ini menunjukkan adanya kemandirian kekuasaan kehakiman. Indentfikasi kekuasaan kehakiman bukan semata- mata indepedensi kelembagaan saja tetapi juga indepedensi personal hakim. Lembaga kehakiman dituntut untuk menegakkan hukum yang seadil adilnya demi kepastian dan ketertiban. Dalam ketentuan Pasal 5 ayat 1 Undang Undang no 48 tahun 2009 dinyatakan bahwa" Hakim dan Hakim Konstitusi wajib menggali, mengikuti dan memahami

\section{${ }^{3}$ Farid Wajdi, Indepedensi dan}

Akuntabilitas Peradilan Dalam buku meluruskan Arah Managemen Kekuasaan Kehakiman,

Sekretariat Jenderal Komisi Yudisial RI.Jakarta, 2018, hlm.79.

${ }^{4}$ Susi Dwi Harriyanti,Politik Hukum

Kekuasaan Kehakiman dalam buku Meluruskan Arah Managemen Kekuasaan

Kehakiman,Sekretariat Jendral Komisi Yudisial Indonesia,Jakarta,2018, hlm.54.

${ }^{5}$ Ibid, hlm.62. nilai nilai hukum dan rasa keadilan yang hidup dalam masyarakat" Dalam hal ini dapat dikatakan bahwa suatu putusan yang adil tidak sekedar menuntut argumentasi dan pertimbangan hukum formal saja, melainkan juga pertimbangan lain di luar hukum bahkan " rasa keadilan " masyarakat juga harus ikut dipertimbangkan ${ }^{6}$. Selain kemandirian Kekuasaan Kehakiman dilakukan pula restrukturisasi lembaga pelaksana kekuasaan kehakiman menjadi 2 organ setara yaitu Mahkamah Agung ( MA) dan Mahkamah Konstitisi ( MK). Selain itu dilengkapi pula kehadiran Komisi Yudisial (KY). Dengan demikian politik hukum di bidang lembaga kekuasaan kehakiman dilaksanakan oleh :

1. Mahkamah Agung dan Badan Peradilan dibawahnya dalam lingkungan Peradilan Umum, Lingkungan Peradilan Agama, Lingkungan Peradilan Militer dan Lingkungan Peradilan Tata Usaha Negara dan Peradilan Syariah Islam di Propinsi Aceh ( pengadilan khusus dalam lingkungan peradilan Agama)

2. Mahkamah Konstitusi ( MK)

3. Komisi judisial, ( jabatan sebagai pengawas eksternal ,pengusul Hakim dan Hakim Agung).

yang $\begin{array}{ccc}\text { Setiap } & \text { Warganegara } & \text { Indonesia } \\ \text { baik } & \text { mempunyai } & \text { kewajiban }\end{array}$ menjunjung tinggi hukum yang berlaku dalam rangka mewujudkan Negara Indonesia sebagai Negara hukum. Oleh karena itu diperlukan rasa tanggungjawab dan kesadaran bagi setiap warganegaranya yang diwujudkan dalam tingkah laku dan tindakan dari setiap orang yang ada di Indonesia. Hakim merupakan aktor utama dalam kekuasaan kehakiman memiliki tanggungjawab untuk mengadili, memeriksa dan memutus perkara. Seorang hakim tetap harus memutus suatu perkara

\footnotetext{
${ }^{6}$ Opcit., hlm. 130.
} 
yang datang kepadanya meskipun perkara tersebut tidak jelas, tidak lengkap, bahkan tidak ada aturannya. Dalam hal ini Hakim harus berusaha menggali atau melakukan penemuan hukum ( Rechtsvinding). Di muka bumi Hakim selalu diibaratkan sebagai wakil Tuhan karena mengingat kedudukannya adalah dalam upaya menciptakan suatu "keadilan, kepastian dan kemaslahatan hukum. Oleh karena itu kapasitas seorang hakim adalah jaminannya. Suatu realitas belum lenyap yang mencederai kekuasaan kehakiman misalnya masih adanya mafia hukum (judicial corruption) yang dilakukan Hakim dan aparat Pengadilan. Seperti yang terjadi di Pengadilan Negeri Tangerang seoreang Hakim tertangkap tangan karena telah menerima suap bersama seorang panitera dan advokat.Disamping itu tidak sedikit pula Hakim yang terbukti melanggar Kode Etik dan Pedoman Perilaku Hakim ( KEPPH). Tetapi keadaan ini tidak saja hanya terjadi pada lingkungan peradilan di bawah Mahkamah Agung, tetapi pada Hakim Mahkamah Konstitusi juga tidak luput dari skandal suap dan pelanggarann Etik dan professional.

Nilai kepercayaan akan menjalin hubungan harmonis dalam kehidupan bermasyarakat dan bernegara, tetapi akan menjadi sebaliknya justru akan timbul kekacauan , ketidaktentraman atau tidak adanya suatu kedamaian apabila nilai kepercayaan ini telah hilang atau mengalami erosi didalam kehidupan bermasyarakat. Ketidak percayaan masyarakat akan timbul dan kewibawan hukum akan menurun, apabila masyarakat melihat kenyataan bahwa penegak hukum atau pengemban hukum justru melakukan perbuatan yang bertentangan dengan nilainilai hukum yang seharusnya, seperti nilai kebenaran, nilai keadilan, kejujuran, kepercayaan dan cintakasih antar sesama, ,yang seharusnya ditegakkan. Secara faktuil dalam kehidupan masyarakat, sebagai akibat dari keadaan peradilan dikatakan " kacau”, hilangnya keteladanan dan tidak tenteramnya kehidupan bermasyarakat, maka menimbulkan keraguan bagi masyarakat untuk mempercayakan penyelesaian masalah masalah mereka kepada aparat dan badan penegak hukum, sehingga akan berlanjut mencari penyelesaian dengan jalan lain yaitu kepada orang orang atau pihak di luar hukum yang mereka percaya atau bahkan menjadi main hakim sendiri. Gejala erosi kepercayaan semacam inilah yang justru harus dicegah.dan harus dilenyapkan.

Dari uraian di atas timbul suatu permasalahan bagi peneliti yaitu bagaimana mewujudkan eksistensi kekuasaan kehakiman yang indepedensi dan bersih dalam menjalankan kewenangannya?

\section{PEMBAHASAN}

Dalam penelitian tentang eksistensi kekuasaan Kehakiman dalam mewujudkan indepedensi peradilan dan peradilan yang bersih, peneliti menggunakan metode pendekatan yuridis normatif yang bersifat deskriptif kualitatif . Dari data sekunder yang diperoleh baik baik yang berupa bahan hukum primer, bahan hukum sekunder dan bahan hukum tertier, untuk selanjutnya data tersebut dianalisis secara kualitatif, sehingga dapat menjawab permasalahan dalam penelitian ini dan pada akhirnya penelitian ini dapat ditarik suatu kesimpulan .

Yang dimaksud dengan kekuasaan kehakiman adalah mandat kekuasan Negara yang dilimpahkan kepada kekuasaan Kehakiman. Selanjutnya yang dimaksud Peradilan adalah tugas yang dibebankan kepada Pengadilan. Tugas utama Pengadilan adalah sebagai tempat untuk mengadili atau memberikan putusan hukum dalam perkara perkara yang diajukan kepadanya. Tindakan khusus dari Hakim Pengadilan adalah memberikan putusan / vonis dan penetapan hakim. Kekuasaan Peradilan terikat pada aturan 
hukum materiil dan peraturan yang bersifat prosedural yaitu hukum acara, yang merupakan batas normatif terhadap kebebasan kekuasaan peradilan dan kebebasan Hakim dalam proses peradilan. Hakim merupakan bagian integral dari system supremasi hukum, saat ini mendapat sorotan yang relatif tinggi dari masyarakat dan media dengan banyaknya kasus kasus yang melibatkan hakim yang telah menggoyahkan eksistensi lembaga Kehakiman. Ketentuan pasal 1 ayat 5 Undang Undang nomor 22 tahun 2004 tentang Komisi Yudisial, dikatakan bahwa secara normatif yang dimaksud dengan “" Hakim"adalah Hakim Agung dan Hakim pada Badan Peradilan di semua lingkungan peradilan yang berada dibawah Mahkamah Agung ( MA) serta Hakim Mahkamah Konstitusi (MK). Setiap Hakim tentunya bercita cita mencapai puncak karier dan puncak tertinggi karier hakim adalah Hakim Agung.Namun tidak semua Hakim dapat menjadi Hakim Agung karena berdasarkan pasal 24A ayat 2 Undang Undang Dasar 1945 hanya hakim yang professional, memiliki integritas dan kepribadian yang tidak tercela adil dan berpengalaman dibidang hukum yang punya peluang menjadi Hakim Agung. Prinsip indepedensi dan akuntabilitas merupakan 2 prinsip kunci dalam kekuasaan kehakiman yang apabila tidak diletakkan secra professional akan saling membahayakan dan akan berpengaruh pada pelaksanaan prinsip Negara berdasarkan hukum yang demokratis. Tanpa adanya kontrol terhadap pelaksanaan kekuasaan dapat berkembang menjadi penyalahgunaan kekuasaan. Oleh karena itu diperlukan balancing atau keseimbangan, sehingga hakim dapat membuat putusan yang bebas dari pengaruh pengaruh lain. Pasal 24 ayat2 Undang undang Dasar ( UUD) t1hun 1945 pasca amandemen ke 3 dikatakan bahwa kekuasaan kehakiman di Indonesia selain dilakukan Mahkamah Agung juga dilakukan oleh Mahkamah
Konstitusi. Selanjutnya sebagai implementasinya diundangkan Undang Undang no 22 tahun 2004 tentang Komisi Yudisial, Komisi Yudisial punya peran penting dalam usaha mewujudkan kekuasaan kehakiman yang merdeka melalui pencalonan hakim agung serta pengawasan terhadap hakim.secara transparan dan partisipatif dan dalam rangka menjaga dan menegakkan kehormatan, keluhuran martabat dan perilaku hakim Komisi yudisial merupakan lembaga Negara yang bersifat mandiri dan dalam pelaksanaan wewenangnya bebas dari campur tangan atau pengaruh kekuasaan lainnya. Komisi yudisial sebagai lembaga yang memiliki wewenang untuk melakukan rekrutmen terhadap Hakim Agung. Sebelumnya pengangkatan Hakim Agung didasarkan system jenjang karier kemudian berubah karena telah dibukanya kesempatan bagi mereka yang non karier dapat menjadi Hakim Agung. Dengan demikian berarti tidak lagi dapat mengandalkan penilaian ataupun koneksi dari Mahkamah Agung. Hal ini mengakibatkan persaingan untuk menjadi Hakim Agung semakin diperketat. Sistem rekrutmenyapun selalu berubahubah, karena untuk mendapatkan formula yang tepat dalam melakukan rekrutmen agar mendapatkan sosok HakimAgung yang berkualitas dan punya integritas yang dapat dipertanggungjawabkan kepada bangsa dan Negara. Komisi yudisial hanya berkedudukan di pusat sedangkan yang diamanatkan pasal 24B Undang Undang Dasar 1945 Komisi Yudisial bertugas untuk melakukan pengawasan eksternal terhadap Hakim diseluruh Indonesia yang jumlahnya 7516 orang yang tersebar di 842 Pengadilan dengan jumlah pegawai yang hanya 200 an orang ${ }^{7}$. Untuk mengatasi keadaan agar dapat dijalankan dengan lebih efektif,

${ }^{7}$ Ihsan Akbar, Merekonstruksi

Hubungan KY dengan Jejaring, Dalam Majalah Komisi yudisial edisi April- Juni 2018, Jakarta, hlm 50 . 
maka dibentuklah suatu kerjasama berbasis masyarakat dengan elemen elemen masyarakat sipil dan Perguruan Tinggi didaerah sebagai mitra atau jejaring Komisi Yudisial, yang berperan sebagai pendukung dan pengontrol. Dengan adanya penghubung, maka kerjasama Komisi Yudisial dengan masyarakat sipil bisa dilakukan langsung oleh penghubung kepada masyarakat sipil.

Kekuasaan Kehakiman dan lembaga Peradilan sebagai bagian dari upaya untuk menjamin dan melindungi kebebasan rakyat yaitu untuk mencegah kemungkinan tindakan sewenang- wenang pemerintah untuk terwujudnya keadilan dalam Negara hukum. Dalam proses peradilan hakim seharusnya tunduk pada hukum dan tidak tunduk kepada pemerintah ataupun instruksi dari organ judisial atau administratif yang lebih tinggi. Dalam penyelenggaran sengketa hukum oleh kekuasaan kehakiman yang merdeka atau hakim yang bebas merupakan dasar bagi berfungsinya system hukum dengan baik . Pada bab pendahuluaan telah diketahui bahwa tidak sedikit jumlah hakim yang berperilaku melanggar atau diduga melanggar Kode Etik dan Pedoman Perilaku Hakim ( KEPPH), hal ini tentunya sangat mencederai kemuliaan profesi Hakim, menodai kewibawaan dan akan berakibat semakin menurunkan kepercayaan masyarakat terhadap badan peradilan. Dengan ternodanya kemuliaan pofesi hakim, maka sekaligus mencederai rasa keadilan masyarakat khususnya merugikan kepentingan terhadap pencari keadilan ( Justiciabelen). Keadaan tersebut tentunya sangat memprihatinkan dan menunjukkan bahwa betapa gersangnya pemahaman Hakim -Hakim pelanggar KEPPH tersebut terhadap muatan KEPPH. Implementasi terhadap kode etik dan pedoman perilaku Hakim dapat menimbulkan kepercayaan atau ketidak percayaan masyarakat kepada putusan pengadilan. Oleh karena itu Hakim dituntut untuk selalu berperilaku yang berbudi pekerti luhur.. Hakim yang berbudi luhur dapat menunjukkan bahwa profesi hakim adalah suatu kemuliaan ( officium nobile). Dengan demikian sebagai seorang Hakim harus memiliki komitmen dan memegang teguh prinsip serta kode etik sebagai Hakim. Sebagai seorang hakim perlu dijaga komitmen, konsisten dan berpegang teguh pada prinsip. Untuk menjadi Hakim yang baik tidaklah mudah, bukan hanya misalnya hanya sebatas menolak suap atau gratifikasi saja karena banyak sekali ukuran dikatakan hakim yang baik dan professional.. Oleh karena itu kita perlu Komisi yudisial untuk mengawasi hakim dari luar terkait perilaku hakim dan juga perlu Mahkamah Agung untuk mengawasi dari dalam. Dengan maksud agar Hakim Indonesia menjadi lebih baik dan bermartabat dan marwahnya terjaga.

.Untuk mewujudkan kekuasaan kehakiman yang merdeka Komisi yudisial punya peran penting, yaitu melalui pencalonan Hakim Agung serta dengan melakukan pengawasan terhadap Hakim yang transparan dan partisipatif guna menegakkan kehormatan dan keluhuran martabat serta menjaga perilaku Hakim. Sebelum kehadiran Komisi yudisial, Hakim Agung dipilih oeh Ketua Mahkamah Agung. Peran Dewan Perwakilan Rakyat ( DPR) tak kalah pentingnya dalam mewujudkan kemerdekaan kehakiman. DPR berwenang memberikan persetujun calon Hakim Agung yang diusulkan Komisi yudisial Dengan demikian dapat dikatakan bahwa suatu peradilan harus independent, tidak memihak (impartial), competent, diselenggarakan secara jujur ( failtial) dan secara terbuka ( public hearing.) . Dalam hal ini antara harus ada keseimbangan antara Dewan Perwakilan Raktyat, Presiden dan Mahkamah Agung melalui mekanisme Checks and Balances sehingga kekuasaan legislative ,eksekutif, dan judisial dapat saling mengendalikan 
dan saling mengimbangi, sehingga tidak terjadi suatu tindakan kesewenangwenangan atau dominasi diantara lembaga satu dengan ]embaga lainnya.

Sebagaimana kita ketahui bahwa hukum merupakan perwujudan atau manifestasi dari nilai kepercayaan. Akan menjadi suatu hal yang wajar apabila para penegak hukum diharapkan sebagai orang yang sepatutnya dipercaya yang pada hakekatnya harus menegakkan wibawa hukum, yang berarti menegakkan nilai kepercayaan di dalam masyarakat. Nilai kepercayaan merupakan salah satu nilai atau kepentingan masyarakat yang perlu selalu dipelihara, ditegakkan dan dilindungi. . Hal ini dapat terlihat umpamanya pada perilaku seoranng penegak hukum yang tugas yuridisnya sebagai aparat penegak hukum mengusahakan ketaatan atau kepatuhan hukum warga masyarakat, tetapi justru penegak hukum itu sendiri berperilaku sebaliknya, sehingga tidak dapat dijadikan suatu teladan oleh warga masyarakat. Masyarakat berhak untuk mendapat jaminan kepastian hukum dan keadilan. Oleh karena itu aparat penegak hukum harus berlaku adil, tidak tajam kebawah tumpul keatas. Masyarakat bersama Komisi Yudisial harus bekerjasama untuk mewujudkan peradian yang bersih di Indonesia.

$$
\text { Dalam amandemen Undang }
$$

Undang Dasar 1945 juga diatur pembentukan lembaga Negara dalam lingkup kekuasaan yudisial selain Mahkamah Agung (MA) yaitu Mahkamah Konstitusi ( MK) dan Komisi yudisial ( $\mathrm{KY}$ ) sehingga pelaku kekuasaan kehakiman adaMA dan MK didukung oleh KY yang memiliki kewenangan terkait dengan kekuasaan kehakiman. Pasal 24 ayat2 Undang undang Dasar ( UUD) tahun 1945 pasca amandemen ke 3 dikatakan bahwa kekuasaan kehakiman di Indonesia selain dilakukan Mahkamah Agung juga dilakukan oleh Mahkamah Konstitusi. Selanjutnya sebagai implementasinya diundangkan Undang Undang no 22 tahun 2004 tentang Komisi Yudisial, Komisi Yudisial punya peran penting dalam usaha mewujudkan kekuasaan kehakiman yang merdeka melalui pencalonan hakim agung serta pengawasan terhadap hakim.secara transparan dan partisipatif dan dalam rangka menjaga dan menegakkan kehormatan, keluhuran martabat dan perilaku hakim. Keberadaan KY pada hakekatnya menjadi pradigma baru dalam menjaga independensi kekuasaan kehakiman disamping bertujuan untuk mencegah pengaruh dari pemerintah sekaligus untuk mengurangi subyektivitas dan ekslusivitas dalam rekrutmen dan pembinaan hakim.

Hukum adalah seperangkat peraturan tentang tingkah laku manusia yang diakui sekelompok masyarakat, disusun oleh orang yang diberi wewenang oleh masyarakat itu, berlaku dan mengikat untuk seluruh anggota masyarakat dalam suatu Negara ${ }^{8}$ untuk membatasi tingkah laku manusia agar tingkah laku tersebut dapat terkontrol dengan baik, dapat berupa peraturan atau ketentuan-ketentuan tertulis maupun tidak tertulis yang mengatur kehidupan manusia dan menyediakan sanksi bagi siapapun yang melanggarnya Hukum tentunya sangat erat hubungannya dengan keadilan. Setiap hukum yang dilaksanakan ada tuntutan untuk memperoleh suatu keadilan. Oleh karena itu apabila hukum tanpa keadilan akan siasia, sebagai akibatnya hukum akan menjadi tidak berharga dihadapan masyarakat.Sedangkan tujuan dari hukum itu sendiri adalah bersifat universal seperti ketertiban, ketenteraman, kedamaian, kesejahteraan dan kebahagiaan di dalam tata kehidupan bermasyarakat. Beberapa fungsi hukum diantaranya adalah sebagai alat pengatur tata tertib hubungan masyarakat, sebagai sarana untuk

\footnotetext{
${ }^{8}$ Abdul Manan, Prof Dr.Drs.SH.SIP., MHum, Hukum Dinamika Politik Hukum Di Indonesia, Kencana, Jakarta,2018, hlm 7
} 
mewujudkan keadilan social lahir dan batin, sebagai sarana penggerak pembangunan, serta sebagai fungsi kritis.

$$
\text { Di Indonesia “ keadilan” }
$$

digambarkan dalam Pancasila sebagai dasar Negara Republik Indonesia, yaitu dalam sila ke lima " keadilan sosial bagi seluruh rakyat Indonesia". Keadilan disini tentunya didasari dan dijiwai oleh hakekat keadilan kemanusiaan yaitu keadilan dalam hubungannya manusia dengan dirinya sendiri, manusia dengan manusia lainnya, manusia dengan masyarakat, bangsa dan negara serta hubungan manusia dengan Tuhannya." Pernyataan "keadilan sosial" berarti keadilan yang berlaku dalam masyarakat disegala bidang kehidupan baik materiil maupun spiritual yaitu yang menyangkut adil baik dibidang hukum, ekonomi, politik, sosial dan kebudayaan. ${ }^{10}$

Untuk mewujudkan penegakkan hukum yang dicita-citakan, hakim dalam memeriksa mengadili dan memutus suatu perkara dilindungi dan diberi kekuasaan yang merdeka dan bebas oleh Negara dari berbagai intervensi pihak manapun dan dalam bentuk apapun. Hal ini menunjukkan sebagai jaminan ketidak berpihakan hakim , kecuali terhadap hukum dan keadilan demi terselenggaranya Negara hukum Republik Indonesia. ${ }^{11}$ Syarat transparansi yang harus dianut, merupakan salah satu syarat untuk menciptakan good governance. Transparansi maksudnya adalah keterbukaan disemua level dan kekusaan dan jabatan, dipusat sampai daerah dengan pengertian transparan melalui semua fungsi managemennya mulai dari

${ }^{9}$ Agus Santoso,Prof, Dr. SH.MH, Hukum , Moral, \& Keadilan Sebuah Kajian Filsafat

Hukum, Kencana, Jakarta, 2012, hlm 87. ${ }^{10}$ Ibid.

${ }^{11}$ Frans H Winarta, Indepedensi dan imparsialitas Hakim Makna Suara Pembaharuan 4 Oktober 2013 , hlm 10 planning, organizing, actuating, budgeting, coordinating dan controling ${ }^{12}$

Kekuasaan Kehakiman di Indonesia dijalankan Mahkamah Agung bersama sama badan peradilan dibawahnya,( yang dibedakan antara perdilan umum dan peradilan khusus) adalah kekuaasaan untuk memeriksa atas perkara perkara yang diserahkan kepadanya, untuk menegakkan hukum dan keadilan berdasarkan peraturan perundang undangan. Badan yang memegang kekuasaan kehakiman dan peradilan harus bekerja dengan baik sehingga akan dihasilkan putusan putusan yang obyektif dan tidak memihak dan menjunjung tinggi hukum dan keadilan. Sehubungan dengan hal tersebut maka kekuasan kehakiman ini harus bebas dari kekuasaan lain atau pengaruh kekuasaan pemerintahan seperti yang dikehendaki pasal 24 Undang Undang Dasar 1945. Kekuasaan Kehakiman harus independen. Hal ini adalah untuk mencegah timbulnya kesewenang wenangan atau penyalahgunaan kekuasaan. Indepedensi kekuasaan kehakiman saja tidaklah cukup, tapi harus didukung Hakim berintegritas tinggi, bermoral, bermartabat yaitu untuk menghindarkan Hakim yang menyalahgunakan jabatan dengan berlindung dibawah indepedensi kekuasaam Kehakiman tersebut.

Pasal 24 ayat2 Undang undang Dasar ( UUD) tahun 1945 pasca amandemen ke 3 dikatakan bahwa kekuasaan kehakiman di Indonesia selain dilakukan Mahkamah Agung juga dilakukan oleh Mahkamah Konstitusi. Selanjutnya sebagai implementasinya diundangkan Undang Undang no 22 tahun 2004 tentang Komisi Yudisial, Komisi Yudisial punya peran penting dalam usaha mewujudkan kekuasaan kehakiman yang merdeka melalui pencalonan hakim agung serta pengawasan terhadap hakim.secara

${ }^{12}$ Opcit, hlm 80. 
Hj.Eveline Fifiana, Eksistensi Kekuasaan Kehakiman (Judicative Power) Dalam Mewujudkan Indepedensi Peradilan Dan Peradilan Yang Bersih

transparan dan partisipatif dan dalam rangka menjaga dan menegakkan kehormatan, keluhuran martabat dan perilaku hakim. Untuk memperoleh seorang Hakim , Hakim Agung yang bermutu,yang akan memenuhi keinginan masyarakat sebagai seorang pencari keadilan harus dimulai sejak sistem seleksi pengadaan pegawai di lembaga peradilan. Hakim, Hakim Agung harus menjalankan tugas dan kewajibannya secara profesional, independen dan memiliki integritas yang tinggi, memiliki pribadi jujur, memiliki karakter yang kuat dan berkompeten dibidangnya. Indepedensi kekuasaan kehakiman saja tidaklah cukup karena harus disertai hakim yang berintegritas tinggi, bermoral baik dan hakim yang dapat menegakkan keluhuran dan kehormatan martabatnya sehingga tidak terjadi penyalahgunaan kekuasaan ataupun tindakan kesewenangan Hakim. Adanya Hakim yang bersih , bermartabat lah yang dapat membawa perubahan peradilan di Indonesia. Untuk memperoleh seorang Hakim , Hakim Agung yang bermutu,yang akan memenuhi keinginan masyarakat sebagai seorang pencari keadilan, maka harus adanya suatu komitmen yang tinggi, kerja yang transparan dan akuntabel dari Komisi yudisial dalam melaksanakan tugasnya. Indepedensi kekuasaan kehakiman saja tidaklah cukup karena harus disertai hakim yang berintegritas tinggi, bermoral baik dan hakim yang dapat menegakkan keluhuran dan kehormatan martabatnya, dikarenakan dapat berakibat terhadap penyalahgunaan kekuasaan ataupun tindakan kesewenangan Hakim, sehingga harapan untuk dapat mewujudkan kekuasaan yang independen peradilan bersih dan independen sulit dicapai, hanya berangan -angan saja.

\section{PENUTUP}

Dari uraian dalam bab pembahasan di atas dapat disimpulkan bahwa perlu ditekankan suatu kerja keras mereformasi peradilan yang dimulai dari rekrutmen calon Hakim dan calon Hakim Agung oleh Komisi Yudisial yang dilakukan secara transparan, obyektif, partisipatif dengan didukung sistem pengawasan eksternal yang benar, transparan, tegas terhadap perilaku hakim dari Komisi yudisial, disamping itu perlu diperkuat dan didukung dengan pengawasan melekat dan pengawasan internal dalam kelembagaan dari Mahkamah Agung untuk mewujudkan harapan dan cita cita suatu indepedensi peradilan dan peradilan yang bersih. Harus adanya kontrol terhadap pelaksanaan kekuasaan, karena tanpa kontrol kekuasaan dapat berkembang menjadi penyalahgunaan kekuasaan, sehingga kekuasaan kehakiman yang independen yang diamanatkan konstitusi sulit untuk diwujudkan.

\section{DAFTAR PUSTAKA}

\section{Buku-buku:}

Abdul Manan

H.,Prof,Dr.Drs.SH.MHum.,Dinamika

Politik hukum di Indonesia, Kencana Jakarta, 2018

Ahmad Sudiro,Dr.,SH.,MH,MM dan Deni

Bram Ahmad Sudiro,Dr,

SH,MH.,MM,. Hukum dan

Keadilan (Aspek Nasional \&

Internasional), Raja Grafindo

Persada, Jakarta,2013.

Ahmad Santoso,Prof, Dr. SH.MH, Hukum , Moral, \& Keadilan Sebuah

Kajian Filsafat Hukum, Kencana , Jakarta, 2012.

Barda Nawawi Arief, Prof.Dr.SH., Masalah Penegakan Hukum Dan Kebijakan Hukum Pidana Dalam Penanggulangan Kejahatan,Putra Grafika, Jakarta, 2008.

Farid Wajdi, Indepedensi dan
Akuntabilitas Peradilan Dalam
buku meluruskan Arah
managemen Kekuasaan
Kehakiman, Sekretariat Jenderal
Komisi Yudisial RI.Jakarta, 2018 
Hj.Eveline Fifiana, Eksistensi Kekuasaan Kehakiman (Judicative Power) Dalam Mewujudkan Indepedensi Peradilan Dan Peradilan Yang Bersih

Halaman 266-273

Frans H Winarta, Indepedensi dan

imparsialitas Hakim, Suara

Pembaharuan 4 Oktober 2013

Ihsan Akbar, Merekonstruksi Hubungan

KY dengan Jejaring, Dalam

Majalah Komisi yudisial edisi

April- Juni 2018, Jakarta, hlm 50.

Mahfud,Moh.MD,Prof.,Dr., Politik

Hukum di Indonesia, PT.Raja

Grafindo Persada, Jakarta, 2012.

Solly Lubis,Prof.,Dr.,SH., Kebijakan

Publik, Mandar Maju,Bandung ,2007.

Susi Dwi Harriyanti,Meluruskan Arah

Managemen Kekuasaan

Kehakiman dalam buku

Meluruskan Arah Managemen

Kekuasaan

Kehakiman,,Sekretariat Jendral

Komisi Yudisial Indonesia,

Jakarta,2018

\section{Peraturan Perundang Undangan}

Undang Undang Dasar tahun 1945 dan Amandemennya.

Undang Undang nomor 22 tahun 2004

Undang Undang nomor 48 tahun 2009

Undang Undang nomor 24 tahun 2003

Undang Undang nomor 4 tahun 2014 